\title{
TRICHINELLA SPP. IN WILD MESOCARNIVORES IN AN ENDEMIC SETTING
}

\author{
Ivana KLuN ${ }^{1}$, Nada ĆOSIĆ ${ }^{2}$, Duško ĆIRović ${ }^{3}$, Dragan VASILEV ${ }^{4}$, Vlado TeOdorović ${ }^{4}$ \\ and Olgica DJURKOVIĆ-DJAKOVIĆ ${ }^{1 *}$ \\ ${ }^{1}$ National Reference Laboratory for Toxoplasmosis, Centre of Excellence for Food- and \\ Vector-borne Zoonoses, Institute for Medical Research, University of Belgrade, \\ Dr. Subotica 4, P.O. Box 102, 11129 Belgrade, Serbia; ${ }^{2}$ Institute for Biological Research \\ 'Siniša Stanković', ${ }^{3}$ Department for Animal Ecology and Zoogeography, Faculty of \\ Biology and ${ }^{4}$ Department for Food Hygiene and Technology, Faculty of Veterinary \\ Medicine, University of Belgrade, Belgrade, Serbia
}

(Received 4 June 2018; accepted 20 November 2018)

\begin{abstract}
Human trichinellosis and Trichinella infection in pigs are both still endemic in the Balkans, including Serbia. Because of the flow between the sylvatic and the domestic cycle of Trichinella spp., monitoring wildlife has been recommended for the risk assessment of Trichinella spp. infection in swine. We have previously shown the presence of Trichinella infection in wild carnivores including the wolf and the golden jackal, and here we report on Trichinella infection in several other mesocarnivore species. From a total of 469 animals collected between 1994 and 2013, Trichinella larvae were detected in $29(6.2 \%, 95 \% \mathrm{CI}=4.0-8.4)$ animals, including 14 red foxes (4.7\%), 7 wild cats (35\%), 5 beech martens (4.8\%), 2 pine martens (16.7\%), and 1 European badger (6.25\%). No Trichinella larvae were detected in the examined specimens of European polecats, steppe polecats and European otters. Species identification of the Trichinella larvae performed for 18 positive samples revealed T. spiralis in $77.8 \%$ and $T$. britovi in $22.2 \%$ of the isolates. Both species were detected in red foxes and wild cats. The predominance of T. spiralis in wildlife in Serbia indicates the (past or present) spillover of this pathogen from domestic to wild animals.
\end{abstract}

Key words: Trichinella spp., wild mesocarnivores, T. spiralis, T. britovi, sylvatic cycle, domestic cycle, endemic setting

Trichinellosis is one of the most widespread zoonoses in the world. In Europe, the most widespread species of Trichinella genus in domestic and wild animals are Trichinella spiralis and T. britovi (Pozio, 2007; Pozio et al., 2009), respectively predominant in the domestic and the sylvatic cycle of parasite transmission. However, spillover between these cycles may occur, usually via synanthropic animals (rats, red foxes, mustelids, cats, dogs), facilitated by human activities such as inadequate disposal of game carcasses or unregulated garbage

*Corresponding author; E-mail: olgicadj@imi.bg.ac.rs, Phone: 00381 (11) 2685-788 
dumps (Pozio, 2000). Consequently, Pozio et al. (2009) have called for the monitoring of wildlife to make an appropriate risk assessment for the transmission of Trichinella to the pig population. Accordingly, the European Commission Implementing Regulation (EU) 2015/1375 recommended risk-based monitoring of Trichinella infection in wildlife.

In Europe, the major region endemic for Trichinella infection is the Balkans. In Serbia, efforts for the control of the domestic cycle are therefore continuously in place, but the sylvatic cycle has come into focus only recently. The first report of $T$. britovi in a wild boar in 2011 was followed by reports in a few specimens of other wildlife species (Cvetković et al., 2011; Petrović et al., 2012; Zivojinovic et al., 2013).

We have recently finalised a large investigation of Trichinella infection in wildlife in Serbia, where sample collection in co-operation with local hunters had started over 20 years ago. One half $(49.5 \%)$ of the examined wolves were Trichinella infected, of which all larvae were identified as T. britovi (Teodorović et al., 2014), whereas in a quite large series of 738 golden jackals, Trichinella was found in $16.5 \%$, of which, however, more than two thirds harboured T. spiralis and one third $T$. britovi (Ćirović et al., 2015). We here bring this investigation to an end by reporting the findings of Trichinella spp. in several species of mesocarnivores.

\section{Materials and methods}

A total of 469 mesocarnivore specimens were collected over a 20 -year period between 1994 and 2013, from most of the territory of Serbia. Game animals included 296 red foxes (Vulpes vulpes), 20 wild cats (Felis silvestris), 12 pine martens (Martes martes), 103 beech martens (Martes foina) and 16 European badgers (Meles meles), collected in co-operation with local hunting organisations as part of regular carnivore control, while the protected species included $15 \mathrm{Eu}-$ ropean polecats (Mustela putorius), three steppe polecats (Mustela eversmanii) and four European otters (Lutra lutra), collected exclusively as road kills. All species were identified according to morphological characters; wild cats, specifically, were identified based on careful examination of coat colour and pattern (Ragni and Possenti, 1996). For each animal, the date of death, sex (261 males, 188 females, 20 unidentified), and collection site were noted. The tongue and masseters were removed in the field and frozen at $-18{ }^{\circ} \mathrm{C}$ until testing for Trichinella. A total of $20 \mathrm{~g}$ of muscle tissue - or $10 \mathrm{~g}$ in case of the smaller animals including martens and polecats - was analysed by artificial digestion according to the standard protocols (Gamble et al., 2000; European Commission, 2005). Trichinella larvae were counted under a microscope and the worm burden was expressed as the number of larvae per gram of muscle tissue (LPG) \pm standard deviation. All collected larvae were stored in $90 \%$ ethyl alcohol at $-18{ }^{\circ} \mathrm{C}$ until 
molecular identification (however, 11 samples collected at an early stage of the study were subject to degradation of substrate or DNA during storage due to a freezer breakdown). DNA was extracted from a pool of ten larvae per sample using the GeneJET Genomic DNA Purification Kit (Thermo Fisher Scientific, Waltham, MA, USA) according to the manufacturer's instructions. Extracted DNA was resuspended in $150 \mu \mathrm{l}$ of nuclease-free water and stored at $-20^{\circ} \mathrm{C}$. Identification of Trichinella larvae at the species level was performed by multiplex PCR according to the protocol of Pozio and La Rosa (2009), modified to increase the sensitivity of the PCR reaction to detect mixed species infections in DNA extracted from a pool of larvae as previously described (Teodorović et al., 2014). Pools of ten larvae from three Trichinella reference strains [Trichinella spiralis (code ISS3), Trichinella britovi (code ISS2) and Trichinella pseudospiralis (code ISS13) (kindly supplied by Dr. Edoardo Pozio of the International Trichinella Reference Center - ITRC, Rome, Italy)], representing the species circulating in the Balkan region (Pozio and Zarlenga, 2013), were used as positive controls. Estimation of fragment size was based on comparison with a 50-bp DNA ladder (Fermentas).

\section{Results and discussion}

Of the total of 469 mesocarnivores examined, 29 [6.2\%, 95\% confidence interval $(\mathrm{CI})=4.0-8.4]$ were carriers of Trichinella larvae. Trichinella infection was detected in five of the eight examined species, i.e. in 14/296 red foxes (4.7\%), $7 / 20$ wild cats $(35 \%), 5 / 103$ beech martens $(4.8 \%), 2 / 12$ pine martens $(16.7 \%)$ and $1 / 16$ European badgers $(6.25 \%)$ (Table 1$)$. The examined specimens of European polecats, steppe polecats and European otters were not infected with Trichinella.

These findings are important in several respects. On the one hand, the red fox is regarded as an indicator species for the assessment of sylvatic trichinellosis in Europe (Pozio, 1998). In this context, there seems to be a steady presence of Trichinella infection in the area, as an almost 5\% infection rate in foxes was reported in the neighbouring Croatia as well (rev. in Florijančić et al., 2006). On the other hand, the presented results seem to indicate wild cats as the most frequently infected of the here examined species, and Trichinella infection has already been reported in a single previously examined wild cat in Serbia (Cvetković et al., 2011). Interestingly, a similarly high proportion of infection (33.3\%) among wild cats has recently been reported from the neighbouring Romania, albeit among only six animals (Marian et al., 2015).

Finally, this is the first study to report Trichinella infection in Mustelidae in Serbia. Among the six examined Mustelidae species, Trichinella was detected in three, including the European badger, the pine marten and the beech marten. Although a single badger was found to be positive, it was the animal that had the 
highest intensity of infection (948.3 LPG) ever recorded in wild carnivores in Serbia. The absence of detectable infection in European polecats, steppe polecats and European otters has probably to do with the size of the sample $(\mathrm{n}=15$, three and four, respectively), although Trichinella infection has rarely been reported in these species in Europe (ITRC, 2018).

Table 1

Trichinella infection, larval burden and species identification in wild mesocarnivores in Serbia

\begin{tabular}{|c|c|c|c|c|c|c|c|c|}
\hline \multirow{2}{*}{$\begin{array}{l}\text { Animal } \\
\text { species }\end{array}$} & \multirow{2}{*}{$\begin{array}{l}\text { Examined } \\
\text { (n) }\end{array}$} & \multirow{2}{*}{$\begin{array}{l}\text { In- } \\
\text { fected } \\
\text { (n) }\end{array}$} & \multirow{2}{*}{$\begin{array}{c}\text { In- } \\
\text { fected } \\
(\%)\end{array}$} & \multirow{2}{*}{$\begin{array}{c}95 \% \text { CI } \\
(\%)\end{array}$} & \multirow{2}{*}{$\begin{array}{l}\mathrm{LPG} \pm \mathrm{SD} \\
\text { range }\end{array}$} & \multicolumn{3}{|c|}{ Trichinella species } \\
\hline & & & & & & $\begin{array}{c}T . \\
\text { spiralis }\end{array}$ & $\begin{array}{c}T . \\
\text { britovi }\end{array}$ & $\begin{array}{c}\text { Un- } \\
\text { identified }\end{array}$ \\
\hline Red fox & 296 & 14 & 4.7 & $2.3-7.1$ & $\begin{array}{c}3.1 \pm 2.1 \\
1-6.7\end{array}$ & $8^{\mathrm{a}}$ & $2^{b}$ & 4 \\
\hline Wild cat & 20 & 7 & 35.0 & $14.1-55.9$ & $\begin{array}{c}14.3 \pm 6.7 \\
4.4-24.5\end{array}$ & $5^{\mathrm{c}}$ & $1^{\mathrm{d}}$ & 1 \\
\hline European badger & 16 & 1 & 6.2 & $0-18.1$ & 948.3 & 0 & 0 & 1 \\
\hline Beech marten & 103 & 5 & 4.8 & $0.7-8.9$ & $\begin{array}{c}10.6 \pm 11.8 \\
1.4-27.5\end{array}$ & 0 & $1^{\mathrm{e}}$ & 4 \\
\hline Pine marten & 12 & 2 & 16.7 & $0-37.8$ & $\begin{array}{c}104.2 \pm 141.6 \\
4-204.3\end{array}$ & $1^{\mathrm{f}}$ & 0 & 1 \\
\hline European polecat & 15 & 0 & 0 & - & - & - & - & - \\
\hline Steppe polecat & 3 & 0 & 0 & - & - & - & - & - \\
\hline European otter & 4 & 0 & 0 & - & - & - & - & - \\
\hline Total & 469 & 29 & 6.2 & $4.0-8.4$ & $\begin{array}{c}46.7 \pm 177.4 \\
1-948.3\end{array}$ & 14 & 4 & 11 \\
\hline
\end{tabular}

$\mathrm{CI}$ : confidence interval; $\mathrm{LPG} \pm \mathrm{SD}$ : larvae per gram of muscle tissue \pm standard deviation. ${ }^{a-f}$ District (locality, year for each animal) of hunt (districts endemic for Trichinella infection in bold script): ${ }^{\mathrm{a} B e l g r a d e}$ (Boljevci, 2010); Braničevo (Ram, 2012; Požeženo, 2013; Braničevo, 2013); Podunavlje (Vodanj, 2009; Lipe, 2011; Krnjevo, 2013; Vodanj, 2013); ' Braničevo (Zatonje, 2011); Toplica (Blace, 2010); ' Podunavlje (Krnjevo, 2011, 2012); Pomoravlje (Grabovac, 2011, 2011); ${ }^{\mathrm{d}}$ Raška (Vrdila, 2012); ${ }^{\mathrm{e}}$ Braničevo (Žagubica, 2010); ${ }^{\mathrm{f}}$ Braničevo (Veliko Gradište, 2009)

Species identification of the Trichinella larvae performed for the 18 positive samples available for typing revealed the presence of both $T$. spiralis and $T$. britovi, with a large predominance $(77.8 \%)$ of $T$. spiralis. Both species were detected in red foxes and wild cats, also with $T$. spiralis dominating. This may be considered surprising since $T$. britovi is generally most widespread in sylvatic carnivores in Europe, particularly south of the $-6{ }^{\circ} \mathrm{C}$ January isotherm (Pozio et al., 2009). While it is true that we obtained this result in a rather small sample, a higher proportion of $T$. spiralis in wild animals has previously been observed in Serbia (Cvetković et al., 2011; Petrović et al., 2012; Zivojinovic et al., 2013), 
particularly in the golden jackal (Ćirović et al., 2015). Interestingly, T. spiralis was also detected in a pine marten, which is the first finding of $T$. spiralis as a monoinfection in this mustelid in Europe.

The presence of Trichinella infection in $6 \%$ of the examined mesocarnivores in Serbia and, moreover, the predominance of $T$. spiralis suggest that wild carnivores are important for Trichinella transmission not just in the sylvatic but also in the domestic cycle, probably as a result of feeding on remains and carcasses of domestic animals left on unregulated garbage dumps. These results, along with our previous study in golden jackals (Ćirović et al., 2015), show that several wild animal species may participate in the spillover of Trichinella species between the domestic and the sylvatic cycle, ultimately contributing to the maintenance and spread of infection. Therefore, the control of human and swine Trichinella infection in endemic settings should necessarily include the control of this infection in wildlife, through vigilance in proper waste management as well as adherence to proper hunting practices, and the implementation of riskbased monitoring.

\section{Acknowledgement}

This study was supported by the Ministry of Education, Science and Technological Development of the Republic of Serbia (project grants No. TR 31009, TR 31034 and III 41019).

\section{References}

Cvetković, J., Teodorović, V., Marucci, G., Vasilev, D., Vasilev, S., Ćirović, D. and SofronićMilosavljević, Lj. (2011): First identification of Trichinella britovi in Serbia. Acta Parasitol. 56, 232-235.

Ćirović, D., Teodorović, V., Vasilev, D., Marković, M., Ćosić, N., Dimitrijević, M., Klun, I. and Djurković-Djaković, O. (2015): A large-scale study of the Trichinella genus in the golden jackal (Canis aureus) population in Serbia. Vet. Parasitol. 212, 253-256.

European Commission (2005): Commission Regulation (EC) No. 2075/2005 of 5 December 2005 laying down specific rules on official controls for Trichinella in meat. Off. J. E.U. 338, 6082. (Accessed March 5, 2018). http://eur-lex.europa.eu/legal-content/EN/ALL/?uri=CELEX $\% 3 \mathrm{~A} 32005 \mathrm{R} 2075$

European Commission (2015): Commission Implementing Regulation (EU) 2015/1375 of $10 \mathrm{Au}-$ gust 2015 laying down specific rules on official controls for Trichinella in meat. Off. J. E.U. 212, 7-34. (Accessed March 5, 2018). http://eur-lex.europa.eu/legal-content/EN/TXT/ ?uri $=$ celex\%3A32015R1375

Florijančić, T., Marinculić, A., Antunović, B. and Bošković, I. (2006): A survey of the current status of sylvatic trichinellosis in the Republic of Croatia. Vet. Arhiv 76 (Suppl.), S1-S8.

Gamble, H. R., Bessonov, A., Čuperlović, K., Gajadhar, A. A., Van Knapen, F., Nöckler, K., Schenone, H. and Zhu, X. (2000): Recommendations on methods for the control of Trichinella in domestic and wild animals intended for human consumption. Vet. Parasitol. 93, 393-408.

ITRC - International Trichinella Reference Center (2018): The database of Trichinella strains. (Accessed March 5, 2018). https://www.iss.it/site/trichinella/scripts/reso.asp 
Marian, I., Mihalca, A. D. and Gherman, C. M. (2015): Prevalence of Trichinella spp. infection in large wild carnivore species from Romania between January 2014 and July 2015. Bull. U.A.S.V.M. Vet. Med. 72, 438-440.

Petrović, J., Pušić, I., Apić, J., Milanov, D., Grgić, Ž., Djordjević, V. and Matekalo-Sverak, V. (2012): Sylvatic trichinosis - role of wild animals in cycle of spread of trichinosis in Serbia. Vet. Glasnik 66, 175-183.

Pozio, E. (1998): Trichinellosis in the European Union: Epidemiology, ecology and economic impact. Parasitol. Today 14, 35-38.

Pozio, E. (2000): Factors affecting the flow among domestic, synanthropic and sylvatic cycles of Trichinella. Vet. Parasitol. 93, 241-262.

Pozio, E. (2007): World distribution of Trichinella spp. infection in animals and humans. Vet. Parasitol. 149, 3-21.

Pozio, E. and La Rosa, G. (2009): Trichinella. In: Liu, D. (ed.) Molecular Detection of Foodborne Pathogens. C.R.C. Press, Boca Raton. pp. 851-863.

Pozio, E. and Zarlenga, D. S. (2013): New pieces of the Trichinella puzzle. Int. J. Parasitol. 43, 983-997.

Pozio, E., Rinaldi, L., Marucci, G., Musella, V., Galati, F., Cringoli, G., Boireau, P. and La Rosa, G. (2009): Hosts and habitats of Trichinella spiralis and Trichinella britovi in Europe. Int. J. Parasitol. 39, 71-79.

Ragni, B. and Possenti, M. (1996): Variability of coat colour and markings system in Felis silvestris. Ital. J. Zool. 63, 285-292.

Teodorović, V., Vasilev, D., Ćirović, D., Marković, M., Ćosić, N., Djurić, S. and DjurkovićDjaković, O. (2014): The wolf (Canis lupus) as an indicator species for the sylvatic Trichinella cycle in the Central Balkans. J. Wildlife Dis. 50, 911-915.

Zivojinovic, M., Sofronic-Milosavljevic, Lj., Cvetkovic, J., Pozio, E., Interisano, M., Plavsic, B., Radojicic, S. and Kulisic, Z. (2013): Trichinella infections in different host species of an endemic district of Serbia. Vet. Parasitol. 194, 136-138. 